\title{
Economic Freedom and Entrepreneurial Activity: SOME CROSS-COUNTRY EVIDENCE
}

\author{
Christian Bjørnskov
}

Nicolai J. Foss

SMG WP 15/2006

September 2006 
SMG Working Paper No. 15/2006

September 2006

ISBN: 87-91815-33-9

Center for Strategic Management and Globalization Copenhagen Business School

Porcelænshaven 24

2000 Frederiksberg

Denmark

www.cbs.dk/smg 


\title{
ECONOMIC FREEDOM AND ENTREPRENEURIAL ACTIVITY: SOME CROSS-COUNTRY EVIDENCE
}

\author{
Christian Bjørnskov \\ Department of Economics \\ Aarhus School of Business \\ Prismet, Silkeborgvej 2; 8000 Aarhus C \\ Denmark;ChBj@asb.dk \\ Nicolai J Foss \\ Center for Strategic Management and Globalization \\ Copenhagen Business School \\ Porcelainshaven 24; 2000 Frederiksberg; \\ Denmark; njf.smg@.cbs.dk \\ and \\ Department of Strategy and Management \\ Norwegian School of Economics and Business Administration \\ Breiviksveien 40; N-5045; Bergen; Norway
}

September 19, 2006

Word count (main body): 7,183

JEL CODE: M13, O31, O50

KEYWORDS: Economic freedom, entrepreneurship, cross-country variation.

ACKNOWLEDGMENTS: We are grateful to Keld Laursen for comments on an earlier draft and to the Center for Political Studies, Denmark, for financing part of the work on this paper. 


\title{
ECONOMIC FREEDOM AND ENTREPRENEURIAL ACTIVITY: SOME CROSS-COUNTRY EVIDENCE
}

\begin{abstract}
While much attention has been devoted to analyzing how the institutional framework and entrepreneurship impact growth, how economic policy and institutional design affect entrepreneurship appears to be much less analyzed. We try to explain cross-country differences in the level of entrepreneurship by differences in economic policy and institutional design. Specifically, we use the measures of economic freedom to ask which elements of economic policy making and the institutional framework that are responsible for the supply of entrepreneurship (our data on entrepreneurship are derived from the Global Entrepreneurship Monitor). The combination of these two datasets is unique in the literature. We find that the size of government is negatively correlated with entrepreneurial activity but that sound money is positively correlated with entrepreneurial activity. Other measures of economic freedom are not significantly correlated with entrepreneurship.
\end{abstract}




\section{INTRODUCTION}

Societies do not grow and prosper without entrepreneurs. The history of all rich societies is ripe with entrepreneurs: Julius Caesar's friend Balbus went to Rome from a far-away province (Spain) and worked his way up through the ranks to become one of the richest people in the Empire, and on his way built both theatres and baths; Thomas Edison's inventions both made him one of the most famous people of his age and brought electric light and many other modern appliances to ordinary people; and in more recent years, Bill Gates founded one of the world's largest personal fortunes by bringing the computer age into people's homes. Common to these three individuals and countless other less known is entrepreneurial ability and will. And while culture may vary, it is arguable that the particular characteristics of entrepreneurship are anthropological constants (Mises, 1949; Kirzner, 1997; Russell and Rath, 2002).

Yet, we observe rather large differences in entrepreneurial activity across countries and time, particularly if entrepreneurship is proxied by such measures as self-employment, new firm formation and the like (Blau, 1987; Blanchflower, 2000). Some countries are ripe with entrepreneurs who found firms in many different industries (e.g., United States), while in others new firm formation is more of an exception (e.g., Sweden). In this paper, we try to explain such cross-country differences by differences in economic policy and institutional design. Specifically, we use the well-known economic freedom indices (Gwartney and Lawson, 2005) to ask which elements of economic policy making and the institutional framework that are responsible for the supply of entrepreneurs and the level of entrepreneurship in societies. Our data on entrepreneurship are derived from the Global Entrepreneurship Monitor (http://www.gemconsortium.org), a research consortium that collects cross-national data on numerous aspects of entrepreneurship. The combination of these two datasets is unique in the literature.

In the last two to three decades, interest in institutions (Dixit, 1996; North, 1990), growth (Romer, 1990), and entrepreneurship (Segerstrom, Anant, and Dinopoulos, 1990; Baumol, 1993) has strongly increased in economics (although roughly speaking, interest in institutions and growth is still much larger than interest in entrepreneurship; cf. Bianchi and Henrekson, 2005). In particular, the intersections between these three areas have been fertile 
areas of research. Thus, much of recent growth theory has been concerned with exploring cross-country links betweens institutions (and economic policies) and growth (e.g., Olson, 1982; Barro, 1991; Sachs and Warner, 1997), and there has also been some interest in linking entrepreneurship and growth (Aghion and Howitt, 1992; Wennekers and Thurik, 1999; Audretsch and Thurik, 2001; Carree and Thurik, 2002).

Less interest appears to have devoted to the issue of how institutions and economic policy impact the level of entrepreneurship, ${ }^{1}$ arguably because of the well known difficulties of modelling the entrepreneurial function and measuring the incidence and effects of entrepreneurship (cf. Bianchi and Henrekson, 2005). However, this may be seen as a lacunae in the literature to the extent that the link from the institutional framework and economic policies to growth is meditated by entrepreneurial activity. ${ }^{2}$ In Israel Kirzner's terms, the entrepreneur is the "prime mover of progress" (Kirzner, 1980) and neglecting the entrepreneur implies neglecting an important mechanism in the growth process.

The design of the paper is the following. First, we outline some existing theories of entrepreneurial activity. Most economic theories of entrepreneurship are extremely abstract and do not enter into specific discussions of the institutional and economic policy determinants of entrepreneurship. Accordingly, we provide such a discussion. Secondly, we report a set of cross-country regressions that explain various measures of entrepreneurship and innovation in terms of variables drawn from the economic freedom indices. Finally, we discuss the findings and conclude with a set of policy recommendations for countries wanting to increase their entrepreneurial dynamism.

In sum, the contribution of this paper is to empirically examine the institutional and economic policy determinants of entrepreneurship and innovation, using datasets that while enjoying some use individually have not hitherto been brought together in a single analysis.

\footnotetext{
${ }^{1}$ However, see Audretsch, Thurik and Verheul (2002) for some cross-country comparisons and Kreft and Sobel (2005) for cross-state comparisons in a US context.

2 This is not entirely unproblematic, because, as argued by Baumol (1990), entrepreneurship may well be unproductive and even destructive. For example, entrepreneurship may be exercised in criminal or rentseeking activities. However, Baumol assumes that the supply of entrepreneurship is constant (while its allocation over productive, unproductive and destructive activities may differ). Clearly, this is a strong assumption, and there are reasons to assume that the supply of entrepreneurship is in fact dependent on the returns to entrepreneurship (Kirzner, 1985; Henreksson, 2005).
} 


\section{THEORIES OF ENTREPRENEURSHIP AND ITS DETERMINANTS}

\section{The Phenomenon of Entrepreneurship}

Because entrepreneurs in many ways personify market forces, one might expect entrepreneurs to be the central figures in economics, that is, to be recognized as "the single most important player in a modern economy" (Lazear, 2002: 1). As numerous writers — from Hayek (1946) over Baumol (1968) to Bianchi and Henrekson (2005) - have lamented, the real world importance of entrepreneurs is not reflected in economic theorizing. Yet, what is usually seen as the founding contribution to the economics of entrepreneurship, Richard Cantillon's (1755) Essai sur la nature de commerce en géneral (1755), actually precedes the Wealth of Nations by more than two decades, and many different conceptions of entrepreneurship have been developed in the economics literature. In the following, we briefly survey these. ${ }^{3}$

Entrepreneurship as management. In the entrepreneurship curriculum of many business schools, the phenomenon under investigation has often been "small-business management." Entrepreneurs are pictured as the managers of small, family-owned businesses or start-up companies. Entrepreneurship consists of routine management tasks, relationships with venture capitalists and other sources of external finance, product development, marketing, and so on. Unfortunately, this notion of entrepreneurship is sufficiently elastic to be practically meaningless as it appears to include virtually all aspects of small or new business management, while excluding the identical tasks when performed within a large or established business. Put differently, if entrepreneurship is simply a set of management activities, or any management activity that takes place within a particular type of firm, then it is unclear why we should bother to add this label to those activities.

Entrepreneurship as imagination or creativity. It is common, particularly within the management literature, to associate entrepreneurship with boldness, daring, imagination, or creativity (Begley and Boyd, 1987; Lumpkin and Dess, 1996). These accounts emphasize the personal, psychological characteristics of the entrepreneur. Entrepreneurship, in this

\footnotetext{
${ }^{3}$ More extensive discussions can be found in Barretto (1989), Praag (1999), Bianchi and Henrekson (2005) and Foss and Klein (2005).
} 
conception, is not a necessary component of all human decision-making, but a specialized activity that some individuals are particularly well equipped to perform. ${ }^{4}$

Entrepreneurship as innovation. The most cited conception of entrepreneurship in economics is Joseph Schumpeter's idea of the entrepreneur as innovator (e.g., Segerstrom et al., 1990; Aghion and Howitt, 1992; Baumol, 1993). Schumpeter's entrepreneur introduces "new combinations"- new products, production methods, markets, sources of supply, or industrial combinations - shaking the economy out of its previous equilibrium through a process Schumpeter termed "creative destruction" (Schumpeter, 1911). Realizing that the entrepreneur has no place in the general-equilibrium system of Walras, whom Schumpeter greatly admired, Schumpeter gave the entrepreneur a role as the source of economic change. $^{5}$ Schumpeter carefully distinguished the entrepreneur from the capitalist (and strongly criticized the neoclassical economists for confusing the two). His entrepreneur need not own capital, or even work within the confines of a business firm at all. In Schumpeter's conception, "people act as entrepreneurs only when they actually carry out new combinations, and lose the character of entrepreneurs as soon as they have built up their business, after which they settle down to running it as other people run their businesses" (Ekelund and Hébert, 1990: 569). Thus, even if by innovating the entrepreneur succeeds in establishing a monopoly that give rise to indefinite returns, “... the flow of gains to the entrepreneur in her entrepreneurial role must be very temporary" (Baumol, 1993: 7).

Entrepreneurship as alertness or discovery. The perhaps strongest competitor to the Schumpeterian conception is the notion of entrepreneurship as "alertness" to profit opportunities. While present in Cantillon's and J. B. Clark's notions of entrepreneurship, this concept has been elaborated most fully by Israel Kirzner (e.g., 1997). Kirzner follows Hayek (1968) in describing competition as a discovery process: the source of entrepreneurial profit is superior foresight - the discovery of something (new products, cost-saving technology) unknown to other market participants. The simplest case is that of

\footnotetext{
${ }^{4}$ Note that the relevant personal characteristics can presumably be acquired by contract on the market by purchasing consulting services, project management, and the like. A "non-entrepreneurial" owner or manager, in other words, can manage the day-to-day operations of the firm, purchasing entrepreneurial services on the market as needed. Moreover, the literature does not explain clearly whether imagination and creativity are necessary, sufficient, or incidental conditions for entrepreneurship. Clearly the founders of many firms are imaginative and creative. If not, are they not entrepreneurs?

${ }^{5}$ This includes, but is not limited to, the formation of new business ventures.
} 
the arbitrageur, who discovers a discrepancy in present prices that can be exploited for financial gain. In a more typical case, the entrepreneur is alert to a new product or a superior production process and steps in to fill this market gap before others. Success, in this view, comes not from following a well-specified maximization problem, but from having some knowledge or insight that no one else has - that is, from something beyond the given optimization framework. ${ }^{6}$

Kirzner's entrepreneurs do not own capital; they need only be alert to profit opportunities. Because they own no assets, they bear no uncertainty. Critics have seized on this as a defect in Kirzner's conception. According to this criticism, mere alertness to a profit opportunity is not sufficient for earning profits. To reap financial gain, the entrepreneur must invest resources to realize the discovered profit opportunity. Moreover, excepting the few cases where buying low and selling high are nearly instantaneous (say, electronic trading of currencies or commodity futures), even arbitrage transactions require some time to complete. The selling price may fall before the arbitrageur has made his sale, and thus even the pure arbitrageur faces some probability of loss. In Kirzner's formulation, the worst that can happen to an entrepreneur is the failure to discover an existing profit opportunity. Entrepreneurs either earn profits or break even, but it is unclear how they suffer losses.

Entrepreneurship as judgment. An alternative to the foregoing accounts is that entrepreneurship consists of judgmental decision-making under conditions of uncertainty. Judgment refers primarily to business decision-making when the range of possible future outcomes, let alone the likelihood of individual outcomes, is generally unknown (what Knight [1921] terms uncertainty, rather than probabilistic risk). Judgment is distinct from boldness, innovation, alertness, and leadership. Judgment must be exercised in mundane circumstances, for ongoing operations as well as new ventures. While alertness tends to be passive, judgment is active. Entrepreneurs "are those who seek to profit by actively promoting adjustment to change. They are not content to passively adjust their . . . activities to readily foreseeable changes or changes that have already occurred in their circumstances;

\footnotetext{
${ }^{6}$ Kirzner's view of superior foresight differs from Stigler's concept of search in which the value of new knowledge is known in advance, available to anyone willing to pay the relevant search costs. "Stigler's searcher decides how much time it is worth spending rummaging through dusty attics and untidy drawers looking for a sketch which (the family recalls) Aunt Enid thought might be by Lautrec. Kirzner's entrepreneur enters a house and glances lazily at the pictures which have been hanging in the same place for years. 'Isn't that a Lautrec on the wall?"' (Ricketts, 1987: 58).
} 
rather, they regard change itself as an opportunity to meliorate their own conditions and aggressively attempt to anticipate and exploit it" (Salerno, 1993: 123). Those who specialize in judgmental decision-making may be dynamic, charismatic leaders, but they need not possess these traits. Decision making under uncertainty is entrepreneurial, whether it involves imagination, creativity, leadership, and related factors or not.

A definition of entrepreneurship. Drawing on the above contributions to the economics of entrepreneurship, and echoing (Wennekers and Thurik, 1999: 46-7), we define "entrepreneurship as the manifest ability and willingness of individuals" to perceive new economic opportunities and to introduce their ways of seizing these opportunities into the market in the face of uncertainty. Following Schumpeter, these opportunities may consist in new products, new processes, new modes of organization, and new product-market combinations. Individuals may exercise this ability and willingness on their own, as manager/owners of firms, as intrapreneurs within firms, and as part of teams inside firms. They do so by making uncertain decisions on the deployment of valuable resources. In sum, we define entrepreneurship as a behavioral characteristic of persons.

\section{Determinants of Entrepreneurship}

The above summaries of the classical contributions to the economics of entrepreneurship suggest several immediate determinants of entrepreneurship. Thus, Schumpeter and Knight both focus on determinants that are inherent to potential entrepreneurs such as the degree to which a person is "venturesome" (Knight, 1921) or has the "ambition" and "intelligence" to exercise "leadership" (Schumpeter, 1911). In contrast, there is rather little specificity in the classical contributions on the institutional and economic policy prerequisites for (successful) entrepreneurship. Both Knight and Schumpeter stress the availability of credit. Schumpeter also links the exercise of entrepreneurship to the supply of other opportunities for social distinction.

However, one seeks in vain in the classical statements for more precise discussions of the institutional and economic policy antecedents to entrepreneurial activity, perhaps because the notion - now entirely commonplace — that institutions imply systems of incentives was not widespread at the time when Schumpeter and Knight wrote. Moreover, state apparatuses did not have anything like the size they do in contemporary welfare states, 
so it is understandable that the classical contributions missed out on this and in general emphasized individual-level determinants.

A partial exception is constituted by the (admittedly much more recent) work of Kirzner (1985). Kirzner (1985: 11) argues that the opportunity of profit switches on entrepreneurial alertness. Price discrepancies, representing profit opportunies, are "flashing red lights" that alert entrepreneurs to pockets of ignorance in the market. By closing these pockets, that is, exploiting gains from trade, entrepreneurs equilibrate the market. However, the signaling system of the market can be hampered in various ways. Thus, Kirzner argues that government intervention, such as minimum prices, price ceilings, and outright nationalization destroys the informational signaling process of the market. Government intervention which aims to improve market outcomes is based on the usually fallacious presumption that government bureaucrats know in advance what the market will reveal. In addition to this fundamental knowledge problem comes the motivational problem that government bureaucrats, unlike entrepreneurs, do not have sufficient incentives to discover the correct prices.

\section{Institutional Determinants of Entrepreneurship}

How institutions affect the supply and quality of entrepreneurial efforts as well as how it affects whether entrepreneurship is associated with commercial success has been a relatively under-researched area in the mainstream economics, although much applied research in small business economics, economic geography, innovation studies, etc. has dealt with how institutions and economic policy influence small firm formation and the rate of innovation. The set of possible determinants of entrepreneurship is very large indeed, including the size of the government, the degree of administrative complexity/bureaucracy, the tax environment, the intellectual property rights regime, the enforcement of property rights in general, the level of trust, competition law, political freedom, labor laws, social security regime, bankruptcy law, corruption, crime, the ethnic composition of the population, availability of finance capital, etc. Some of these have been examined in previous work (e.g., Brunetti, Kisunko, and Weder, 1997; Grilo and Thurik, 2003). In the following we discuss those determinants that may be related to the notion of "economic freedom," a composite construct that includes such components that all ultimately boil down 
to the security and extent of property rights, but include, for example, the freedom to save, change jobs, contractual freedom, to keep income, etc.

\section{Economic Freedom and Entrepreneurship}

Classical-liberal scholars have very often used the size of government in a broad sense - that is, the extent to which the government intervenes in the economy through government consumption, redistribution through transfer schemes, public investments, and marginal taxation - as a good measure of economic freedom. There are many reasons why the size of government may be expected on apriori grounds to influence entrepreneurship (cf. Mirrlees, 1971).

Most directly, if economic activities in certain industries or sectors have essentially been nationalized, the scope for entrepreneurship is reduced, as nationalization often (but of course not necessarily) implies a public monopoly. This is in most parts of the Western industrialized world clearly the case of child care, health care, and care of the elderly. More indirect governmental control, such as requirements that certain trades be certified, may also reduce entrepreneurial activity for example, because certification amounts to barriers to entry (Demsetz, 1982).

To the extent that a large government is associated high levels of publicly financed provision of various services (e.g., care of the elderly, education, etc.) and with generous social security systems, the incentives to engage in entrepreneurial acts in order to make a living (what may be called "necessity entrepreneurship") are reduced because a relatively high reservation wage is practically guaranteed. However, such schemes also reduce incentives for individual wealth formation which may be expected to negatively influence the level of entrepreneurial activity (Henreksson, 2005: 11). One reason has to do with entrepreneurial judgment being idiosyncratic and often hard to clearly communicate to potential investors (Knight, 1921). The entrepreneur may have to finance his venture himself, at least in the start-up phase. If individual wealth formation is reduced because of generous public transfer schemes, etc., this makes such financing difficult. Moreover, if entrepreneurs are only able to commit little personal capital to their entrepreneurial venture, their signal to potential outside investors concerning their commitment to the venture is correspondingly weaker. 
A large government needs to be financed, ultimately by taxation. As Henrekson (2005: 9) rightly points out,

[i]n order to analyze how the tax system impacts on entrepreneurial behaviour, it is not sufficient to focus on the taxation of owners of firms. To a large extent, the return on entrepreneurial effort is taxed as wage income.

One reason is that parts of the income that accrue from closely held companies may be paid out as wage income (depending on the specific tax regime), and that entrepreneurial activity may be carried out by employees. Rewards for entrepreneurial behaviour in firms (e.g., stock options, bonuses for suggesting improvements, etc.) are taxed as wage income. Henrekson (2005: 14) also points out a high level of taxation moves many household-related services out of the reach for entrepreneurial exploitation.: “... higher rates of personal taxation discourage the market provision of goods and services that substitute closely for home-produced services" (p.15).

A related, yet distinct, item in an overall measure of economic freedom relates to the enforcement of property rights, that is, the extent to which property rights are secure over time (North, 1990; Barzel, 2005). Huge literatures in economic history, intellectual property rights, and innovation stress the importance for entrepreneurial activity at the micro level and economic development at the macro level of property rights being well-defined and enforced. If so, it should be expected that institutional features such as the quality of regulations and the judicial system affects overall level of entrepreneurial activity.

A third important item in an economic freedom measure arguably is sound money (Friedman, 1962), in particular the rate and variability of inflation. While anticipations of future relative prices are important in general for economic decision makers, it is arguable that they matter particularly much for entrepreneurs because entrepreneurs are essentially speculators who receive a residual income (Knight, 1921; Kirzner, 1997). Inflation, and particularly erratic inflation "jams" the signalling effects of relative prices (Friedman, 1977). While this may be less of a problem for risk-loving entrepreneurs, many entrepreneurs may well be risk-averse, particularly those who engage in necessity entrepreneurship or activity within well-developed sectors.

Finally, following Kirzner (1985) public regulation is an important item in an economic freedom measure that is relevant to explaining the prevalence of entrepreneurial 
activity. Arguably, regulations can both help and hinder entrepreneurs who need clear rules and predictable enforcement of those rules. On the other hand, excessive regulations impose burdens on all firms, not the least start-ups, that may be prohibitive. In addition, Baumol (1990) made the point that individuals operating in heavily regulated economic environment may have larger gains from engaging in rent-seeking activities within the public sector what he termed "destructive entrepreneurship" — than in real economic activities.

\section{EMPIRICAL EVIDENCE}

\section{Data Sources, Variables, and Models}

The data used in this study is drawn from three different sources and summarized in Table 1.

\section{Insert Table 1 Here}

First, the dependent variables in the following are from the Global Entrepreneurship Monitor Consortium (GEM) 2001 dataset, a rich large-scale questionnaire survey conducted in 29 countries in representative samples of individuals between 18 and 64 years; in total, approximately 77,000 respondents are included. The data contain answers to a large array of questions on both entrepreneurial activity, the reasons for the activities, how they were financed as well as a battery of background questions. We use three variables constructed from the data. The variables, aggregated at the country level, are: ${ }^{7}$

- TEA denotes the level of total entrepreneurial activity, measured by the proportion of respondents in each country who answer that they engaged in the upstart of an economic activity - starting a firm - within the sampling period. As such, the variable measures all firm upstarts regardless of the type of firm and the reason for the activity.

\footnotetext{
${ }^{7}$ For readers who may want to use the GEM database themselves, we use the variables denoted "tea01", "tea01opp" and "tea01nec" to form our aggregate data.
} 
Since the GEM database also includes questions on the reason why respondents may have started a firm of their own, we can distinguish between two broad types of entrepreneurial activity, "opportunity entrepreneurship" and "necessity entrepreneurship".

- $T E A O P P$ is the proportion of the same sample who state that they have engaged in an activity for the reason that they perceive that it represents an economic opportunity to them ("opportunity entrepreneurship"); and

- TEANEC is the proportion of the same sample who state that they engaged in an activity for the reason that they perceived it as "necessary", probably in order to uphold a decent standard of living or, in developing countries, to be able to support their family ("necessity entrepreneurship").

It should be stressed that we thus only measure the actual economic entrepreneurial activity through firm upstarts. Hence, it must be emphasized that we neither capture whatever entrepreneurial activity occurs within existing firms, nor do we in any way measure the potential activity that there may have been in a country, had barriers to such activity not been in place. It is nevertheless clear that there is a substantial amount of crosscountry variation, even in a sample consisting of only 29 countries. The TEA data are distributed between a minimum of $2.9 \%$ of the sample population (Japan) to a maximum of 20.2\% (Mexico); the opportunity index is distributed between 1.3\% (Japan) and 13.3\% (Mexico), while the necessity index is distributed between .2\% (Denmark) and 6.8\% (Mexico). The country-level data on entrepreneurship are summarized in Table 2.

\section{Insert Table 2 Here}

In the following, we control for the logarithm to GDP per capita, measured in purchasing power parity-adjusted US dollars and taken from the Penn World Tables (Heston et al., 2002). We also control for regional variations by including dummies for Sub-Saharan Africa, North Africa and the Middle East, Latin America, and the post-communist countries in Eastern Europe and Central Asia.

Finally, our policy variables are from the freedom data, assembled by the Canadian Fraser Institute and published annually in Gwartney and Lawson (2005). The economic 
freedom indices have been used in a large number of studies documenting, among other things, their substantial effects on economic growth rates (e.g. Berggren, 2003). In the use of this type of data in this context, we follow Kreft and Sobel (2005). We use all five subindices of economic freedom. These are:

- Government size - which measures the extent to which the government intervenes in the economy through consumption, redistribution through transfer schemes, public investments, and marginal taxation. For this particular index, we alternatively split it into its four sub-components.

- Legal quality — which measures the protection and respect for the rights of people to their owl lives and rightfully acquired property. The legal quality index is composed of indicators of judicial independence, impartiality of the courts, protection of intellectual property rights, military interference in law and politics, and integrity of the legal system.

- Sound money — which consists of the rate and variability of inflation and monetary controls, which is a measure of the consistency of monetary policy.

- International trade — which measures the extent of trade and barriers to trade and capital flows, both through actual trade and investment flows and through indicators of tariff and non-tariff barriers to trade and capital.

- Regulatory quality — which is composed of three sub-indices measuring the freedom from government regulations and controls in the labour market, financial markets, and the price controls in the markets for goods and services. These three areas are again composed of: 1) the impact of minimum wages, hiring and firing practices, the share of the labour force with wages set in centralized bargaining, the generosity of unemployment benefits, and the use of conscript military personnel; 2) the percentage of deposits held in privately owned banks, bank competition, percentage of credit extended to the private sector, and the extent of interest rate controls; and 3) price controls, administrative procedures that are obstacles to business, time spent with the bureaucracy, the ease of starting new businesses, and the necessity of irregular payments. 


\section{Some Cross-Country Tests}

We include these variables in a set of simple OLS regressions explaining either the full TEA scores or the TEAOPP or TEANEC variables; Table 3 shows the results of the regressions including all five areas of economic freedom. It also reports the results of using the robust regression technique, which iteratively downweighs potential outlier observations based on the size of their residuals. This alternative procedure thus tests whether results obtained by OLS can be generalized to the full 29-country sample or are driven by single countries, which is an especially important potential problem given our small sample size. The table shows that even with such a small sample, the specification does a fairly good job at explaining the variation. The explanatory power (R squared) varies between 40 and $83 \%$, and all F-tests for joint inclusion of the specification are significant, although the one for TEAOPP fails the $1 \%$ level. The inclusion of all five indices of economic freedom neither proves to a problem as indicated by the low variance inflation factor (See footnote of table $3)$.

\section{Insert Table 3 Here}

It is immediately apparent from the table that economic development is strongly and negatively associated with entrepreneurial activity. Hence, even though such activity forms an important determinant of the growth of income, it tends to decrease with the level of incomes. However, this relation is not significant for opportunity activity (TEAOPP) while being strongly so for necessity activity (TEANEC). As such, development seems to reduce the amount of entrepreneurial activity which is caused by the need to engage in such activity, which is the main reason for the latter type while not necessarily reducing the perceived opportunities. The table also shows that, as of 2001, the post-communist countries do not deviate systematically from other comparable countries. Even though one might fear so, we do not find any sign of path dependency of a system that strongly discouraged private activity.

Turning to the policy variables, we first of all find that the size of government is strongly positively related to both total activity as well as the shares arising from opportunity or necessity. Remembering that a larger score on this index means less 
government intervention, this is quite clear evidence of a depressing effect of government activity, which we explore further in Table 4 below. The estimate suggests a substantial effect, as a one standard deviation improvement results in a rise in entrepreneurial opportunity activity of roughly $85 \%$ of a standard deviation. Second, we fail to find any effects of legal quality, the freedom to trade internationally, or the extent of the regulatory framework. ${ }^{8}$ We do, however, also find evidence of a strong effect of having access to sound money on both the level of total activity as well as on opportunity and necessity entrepreneurship. Here, a one standard deviation improvement of sound money is associated with an increase of $53 \%$ of a standard deviation of TEAOPP and a $49 \%$ increase of TEANEC. The effect is evidently somewhat stronger for entrepreneurial activity based on the presumption of opportunity, yet it is not entirely robust to being estimated by robust regressions as the insignificance of sound money using either TEA or TEAOPP is due to the influence of the three richest countries in the sample. Once excluded, all results are significant and robust. The same result applies if we instead use the logarithm to the sound money index, which has the effect of allowing for larger effects of having very poor monetary consistency (low scores). The reason for this is most likely that once passed a certain threshold of economic development, virtually all countries have set up independent monetary authorities to ensure that citizens have access to stable and predictable money. As such, there is very little variation at the top of the sound money index, which prevents identification of an effect in relatively rich countries.

In sum, Table 3 shows substantial evidence for the effects of two types of economic freedom on the level of entrepreneurial activity. However, the government size index covers a fairly disparate set of sub-indices. We therefore split this index into its component parts in Table 4, in which we keep the logarithm to GDP, the post-communist dummy and the sound money index in the specification while excluding the three insignificant freedom indices. It should also be noted that for three of the four sub-indices, we use the underlying real data. Hence, "government consumption" is measured as the share of government consumption in total consumption; transfers and subsidies as a percentage of total GDP; and public investment as a share of total investments. The exception is the (lack of marginal) taxation index, which we keep as an index since it includes both the size of marginal taxes as well as

\footnotetext{
${ }^{8}$ It should be noted that if we instead use actual trade volumes, which can also be obtained from the Penn World Tables, we obtain the same non-result as with the trade index from the Fraser Institute.
} 
the share of the labour force that face the highest marginal tax rate. Again, the regressions do a fairly decent job of explaining the cross-country variation although the $\mathrm{R}$ squared is much larger when TEANEC is the dependent variable, which is due to the strong and significant impact of economic development. ${ }^{9}$

This point is clear as (the logarithm to) GDP per capita is consistently significant with a very large coefficient in the first four columns while it only becomes significant in one of the four right-hand side columns by coincidence. Again, the post-communist dummy is never significant, indicating that the Eastern European countries have rapidly come to resemble the rest of the Free World on this count. Likewise, sound money is significant throughout the table with both TEANEC and TEAOPP as the dependent variable.

\section{Insert Table 4 here}

Turning to the government size variables and starting in the four left-hand columns of Table 4, in which the necessity component of total entrepreneurial activity is the dependent variable, only one of the four underlying variables is significant. ${ }^{10}$ This variable, government consumption, may proxy for unemployment benefits and other welfare arrangements that lower the chances of having to set up a business out of necessity.

The results are different when we turn to the determinants of necessity entrepreneurship. First of all, the share of total consumption pertaining to the government sector has a strong negative influence on TEAOPP. The coefficient, which is almost three times larger than with TEANEC, indicates that a one standard deviation to government consumption in this sample would induce a loss of opportunity entrepreneurship of about $90 \%$ of a standard deviation. Second, the share of transfers and subsidies in total GDP also exerts a negative influence on TEAOPP. Here, the estimate suggests that a one standard deviation increase in transfers would induce a loss of about $70 \%$ of a standard deviation.

\footnotetext{
${ }^{9}$ Naturally, we have also performed tests with the three constituent subindices - labour, credit and business regulations - forming the overall regulation variable. These results are not reported here as they show no association. Hence, the extent of regulations and controls in the labour market seem unassociated with entrepreneurship in this sample even though other studies have argued for a strong correlation (e.g. Kreft and Sobel, 2005).

${ }^{10} \mathrm{It}$ is worth mentioning that the regressions with public investment contain many missing observations. If we attempt to substitute the missing observations with data from other sources, we get a negative association between necessity entrepreneurship and public investment, but no relation with opportunity activity.
} 
Finally, the lack of taxation index also has a positive influence, that is, raising the marginal income tax rate or expanding the share of the labour force paying this rate affects the level of opportunity entrepreneurship negatively. The estimate here suggests that a one standard deviation deterioration of the index would induce a loss of about $40 \%$ of a standard deviation.

Overall, we thus find that both the access to sound money and three different components of government size are strongly associated with national levels of opportunity entrepreneurship while sound money and one of the government indices are associated with necessity entrepreneurship. In the following, we discuss the potential reasons for these effects and their economic significance.

\section{DISCUSSION}

First, we summarize the overall findings pertaining to government size in Figure 1, which reports the average level of entrepreneurial activity in the half of the sample with a small government sector and a large government sector, respectively. The figure also provides a "feel" for the size of the differences as the height of the columns are percent of the sample average.

\section{Insert Figure 1 here}

\section{Exemplifying the Results}

The figure provides an illustration of the economic significance of the size of government. If, for example, Denmark was to raise its current score on the government size index (3.75) to the average of the remaining four areas (8.5), it would raise its TEAOPP by about eight points. While this is quite clearly an overestimate by being more than two standard deviations of the TEAOPP variable - the GEM survey shows that only about $4.5 \%$ of the Danish population engage in entrepreneurship - it nevertheless indicates the substantial importance of having an oversize government sector. Differences in individuals' access to sound money are also important but with about half the effect as that of the overall government index.

That government consumption has an effect on the level of necessity entrepreneurship should not be surprising, regardless of whether one holds a statist or classical-liberal view of 
the economy, as this variable includes both unemployment benefit expenditures and various public goods that, if not provided by the government, might entail a financial burned for the poor. However, the effect on opportunity entrepreneurship is approximately three times larger than that on necessity entrepreneurship. This finding clearly contradicts the popular claims by Scandinavian politicians, vigorously repeated in Southern European media, that the "welfare state" increases the economic dynamism by protecting people from adverse effects of failing. ${ }^{11}$ Instead, the empirical findings rather clearly indicate that central traits of the welfare state - strong redistribution by either public goods, reflected in government consumption and public investments, or high marginal taxation - are all strongly negatively associated with opportunity entrepreneurship.

On a note of caution, it is important to stress that our results do not inform about the survival of firms resulting from entrepreneurial activities, only the likelihood of such activity occurring. It is therefore entirely possible that a casual examination of the crosscountry differences in total entrepreneurial activity might overstate the benefits of entrepreneurship potentially available to single countries if there is either: 1) country-level decreasing marginal returns to total activity; or 2) that a higher level of activity also reflects a larger proportion of such activities failing. However, we must also stress that although entrepreneurial activity is probably a necessary condition for economic development, even in the Soviet Union under Stalin bureaucrats knew this fact and consequently allowed for some level of private initiative (Gregory and Harrison, 2005). Hence, the cross-country differences should neither be under- nor overestimated, but simply treated with the usual caution.

\section{Related Work}

The present study forms part of the small literature on macroeconomic determinants of entrepreneurship as well as the much larger literature on economic freedom and economic growth. In this paper, we primarily take Kreft and Sobel's (2005) US findings to a crosscountry context, replicating one of their findings while producing another that probably by definition cannot be obtained in national comparisons as monetary policy is national by nature. First, we bring Henrekson's (2005) thoughts on welfare state characteristics and

\footnotetext{
${ }^{11}$ See also Henreksson (2005) for an excellent analysis of how the welfare state (in casu: the Swedish welfare state) stifles incentives for entrepreneurship.
} 
entrepreneurship to a cross-country test, which provides strong support for his theoretically valid notion that excessive government interventions and direct government activity in the economy crowds out private entrepreneurship. Naturally, we cannot say whether government size mainly affects the context in which potential entrepreneurs work and their incentives to unfold their entrepreneurial abilities, or whether systems with large governments instead mainly limit entrepreneurship by transforming norms and privately held beliefs about society. ${ }^{12}$ On the other hand, the finding that citizens' access to sound money, i.e. the existence of a consistent and predictable monetary policy, also adds to entrepreneurship cannot be ascribed to beliefs or incentives. Contrary to government size, it is an entirely contextual factor that limits prospective entrepreneurs' access to financing their entrepreneurial endeavors. An inconsistent monetary policy will also tend to bring noise to the economic signals that Kirzner (1985) argues are crucial to the discovery of entrepreneurial options.

Our paper also provides an addition to the quite extensive literature on economic freedom. This literature has first and foremost demonstrated that aspects of economic freedom and other institutional measures are strongly associated with economic performance and economic growth (Grubel, 1998; Carlsson and Lundström, 2001; Berggren, 2003; de Haan et al., 2006). Whether this association comes about through the effects of economic freedom on factor accumulation or productivity growth is still uncertain. However, using a set of alternative institutional indices related to economic freedom, Méon and Weill (2006) find evidence suggesting that such factors are strongly related to total factor productivity.

Our study, holding its obvious limitations in mind, suggests that at least part of the association may come about through the effects of economic freedom on the degree of entrepreneurship and thus the dynamism in the economy. Here, both direct and indirect channels may be important. The standard policy focus is on high-tech entrepreneurial activity having companies such as Microsoft, Intel or Vestas as only a few obvious examples. Some firm start-ups may naturally end up as major international factors, and increased entrepreneurial activity resulting from increased economic freedom will probably

\footnotetext{
${ }^{12}$ While this to seem might seem a slightly farfetched possibility, it is worth stressing that QJE argue theoretically for the risk that welfare states can undermine citizens' economic norms. Mokyr (2006) makes a similar argument that cultural beliefs played an important role in the Industrial Revolution, which was above anything else an entrepreneurial event.
} 
increase the likelihood that such firms arise. As Mokyr (2006) emphasizes, for long-run growth to occur, sustained growth of knowledge and technology is necessary and that such growth comes about "because in each society, there are people who are creative and original, and motivated by some combination of greed, ambition, curiosity, and altruism". It seems to us that Mokyr's individual characteristics are stumblingly close to a standard definition of an entrepreneur, yet the main point of Mokyr's chapter in the Handbook of Economic Growth is that these characteristics can only be employed fully in countries with the proper institutional framework, that is, in an environment of what would here be termed "economic freedom."

Yet, it should also be stressed that entrepreneurial activity need not be of a sophisticated technological nature to add to economic performance. As stressed by Hayek (1968) many years ago, economic competition has important dynamic effects. Part of the effect of economic freedom on growth could therefore arise from more mundane reasons, for example if new firms increase the competition in product markets or in the production of factor inputs and intermediate goods. Given that economic freedom, through its effects on entrepreneurial activity, increases the competition and efficiency in intermediate goods markets, it could also result in improved efficiency in the production of final goods and thereby in improved economic performance.

As such, while we must stress that there are considerable limits to which conclusions one can derive from cross-country empirical work consisting of only 29 countries, the findings in this paper are both easily interpreted within standard theory of entrepreneurship, which it provides a test of, as well as fitting within a broader and much more extensive literature on economic freedom. With the necessary qualifications in mind, we therefore outline the conclusions and discuss implications in the final section.

\section{CONCLUSIONS}

To sum up, the contribution of this work is to report a set of cross-country tests of the relation between entrepreneurship and economic freedom, basing our findings on existing theoretical literature. As such, we follow in the footsteps of Kreft and Sobel (2005) who show that across the US states, the level of entrepreneurial activity is significantly associated with economic freedom. We find that both the size of government and the quality of the monetary policy are strong determinants of entrepreneurship across a small sample of 
29 countries for which there are comparable data on entrepreneurship. The access to sound money appears to be critical to both opportunity and necessity entrepreneurship. On the other hand, only governments' share in total consumption affects necessity entrepreneurship while both government consumption, transfers and subsidies and the extent of taxation are negatively associated with opportunity entrepreneurship. Holding the limitations of our paper in mind, we must conclude that these findings outline what may be costs of a lack of economic freedom not often discussed in the literature. 


\section{REFERENCES}

Aghion, Philippe and Peter Howitt. 1992. A Model of Growth Through Creative Destruction. Econometrica 60: 323-351.

Ali, Abdiweli M. and W. Mark Crain. 2002. Institutional Distortions, Economic Freedom, and Growth. Cato Journal 21: 415-426.

Audretsch, David B. and Roy Thurik. 2001. Linking Entrepreneurship to Growth. OECD Science, Technology and Industry Working Papers, 2001/2, OECD Publishing.

Audretsch, David B., Roy Thurik, Ingrid Verheul and Sonder Wennekers. 2002. Entrepreneurship: Determinants and Policy in a European-US Comparison. Boston: Springer.

Barretto, Humberto. 1989. The Entrepreneur in Economic Theory. London: Routledge.

Barro, Robert J. 1991. Economic Growth in a Cross-Section of Countries. Quarterly Journal of Economics 106: 407-443.

Barzel, Yoram. 2005. A Theory of the State. Cambridge: Cambridge University Press.

Baumol, William. 1968. Entrepreneurship in Economic Theory. American Economic Review, vol. 58: 64-71.

Baumol, William. 1990. Entrepreneurship: Productive, Unproductive, and Destructive. Journal of Political Economy 98: 893-921.

Baumol, William. 1993. Entrepreneurship, Management, and the Structure of Payoffs. Cambridge, MA: MIT Press.

Berggren, Niclas. 2003. The Benefits of Economic Freedom: A Survey. Independent Review 8: 193-211.

Bianchi, Milo and Magnus Henrekson. 2005. Is Neoclassical Economics still Entrepreneurless? Kyklos 58: 353-377.

Blanchflower, D.G. 2000. Self-Employment in OECD Countries. Labour Economics 7: 471505.

Blau, D. 1987. A Time-Series Analysis of Self-Employment in the United States. Journal of Political Economy 95: 445-467. 
Brunetti, A., G. Kisunko and G. Weder. 1997. Institutional Obstacles to Doing Business: Region-by-Region Results from a Worldwide Survey of the Private Sector, background paper for World Development Report 1997, Policy Research Working Paper 1759, World Bank, Washington D.C.

Cantillon, Richard. 1755. Essai sur la nature de commerce en géneral. Henry Higgs, ed. London: Macmillan, 1931.

Carlsson, Fredrik and Susanne Lundström. 2001. Economic Freedom and Growth: Decomposing the Effects. Working Paper in Economics no. 33, Department of Economics, Göteborg University.

De Haan, Jacob, Susanna Lundström and Jan-Egbert Sturm. 2006. Market-Oriented Institutions and Policies and Economic Growth: A Critical Survey. Journal of Economic Surveys 20 (2), 157-191.

Demsetz, Harold. 1982. Barriers to Entry. American Economic Review 72: 47-57.

Dixit, Avinash. 1996. The Making of Economic Policy: A Transaction Cost Perspective. Cambridge, MA: MIT Press.

Foss, Nicolai and Peter G. Klein. 2005. Entrepreneurship and the Economic Theory of the Firm: Any Gains from Trade? In Rajshree Agarwal, Sharon A. Alvarez, and Olav Sorenson, eds., Handbook of Entrepreneurship: Disciplinary Perspectives. Boston: Kluwer.

Friedman, Milton. 1977. Nobel Lecture: Inflation and Unemployment. Journal of Political Economy 85: 451-472

Gregory, Paul and Mark Harrison. 2005. Allocation under Dictatorship: Research in Stalin's Archives. Journal of Economic Literature 43 (3): 721-761.

Grubel, Herbert G. 1998. Economic Freedom and Human Welfare: Some Empirical Findings. Cato Journal 18 (2), 287-304.

Gwartney, James and Robert Lawson. 2005. Economic Freedom of the World 2005. Downloadable from http://www.freetheworld.com/download.html

Hayek, Friedrich A. von. 1946. The Meaning of Competition in idem. 1948. Individualism and Economic Order. Chicago: University of Chicago Press. 
Hayek, Friedrich A. von. 1968. Competition as a Discovery Procedure. In idem. 1978. New Studies in Economics, Politics, Philosophy, and the History of Ideas. London: Routledge.

Henrekson, Magnus. 2005. Entrepreneurship: a Weak Link in the Welfare State? Industrial and Corporate Change 14 (3): 437-467.

Henrekson, Magnus and Nathan Rosenberg. 2001. Designing Efficient Institutions for Science-Based Entrepreneurship: Lessons from the US and Sweden. Journal of Technology Transfer, vol. 26 (3), 207-231.

Heston, Alan, Robert Summers, and Bettina Aten. 2002. Penn World Tables, Version 6.1, Center for International Comparisons (CICUP), University of Pennsylvania, October, 2002.

Kirzner, Israel. 1980. The Prime Mover of Progress. In Israel Kirzner and Arthur Seldon. 1980. The Entrepreneur in Capitalism and Socialism. London: Institute of Economic Affairs.

Kirzner, Israel. 1985. Discovery and the Capitalist Process. Chicago: University of Chicago Press.

Kirzner, Israel. 1997. Entrepreneurial Discovery and the Competitive Market Process: An Austrian Approach. Journal of Economic Literature 35: 60-85.

Klein, Peter G. and Hung Luu. 2003. Politics and Productivity, Economic Inquiry 41: 433447.

Kreft, Steven F. and Russell S. Sobel. 2005. Public Policy, Entrepreneurship, and Economic Freedom. Cato Journal 25 (3): 595-616.

Lazear. Edward M. 2002. Entrepreneurship. National Bureau of Economic Research No. 9109.

Lee, S.Y., Florida, R. and Acs, Z.J (2004) “Creativity and Entrepreneurship: A Regional nalysis of New Firm Formation," Paper No. 1704, Discussion Papers on Entrepreneurship, Growth and Public Policy, Max Planck Institute of Economics, Jena. 
Licht, A. and Siegel, J.I. (forthcoming, 2006) "Social Dimensions of Entrepreneurship, in Casson, M. and Yeung, B (Eds). Oxford Handbook of Entrepreneurship, Oxford, Oxford University Press.

Méon, Pierre-Guillaume and Laurent Weill. 2006. Does Better Governance Foster Efficiency? An Aggregate Frontier Analysis. Economics of Governance 6 (1): 75-90.

Mirrlees, James A. 1971. "An Exploration in the Theory of Optimum Income Taxation. Review of Economic Studies 38: 175-208.

Mises, Ludwig von. 1949. Human Action. London: William Hodge.

Mokyr, Joel. 2006. "Long-Term Economic Growth and the History of Technology", in Aghion, Philippe and Steven Durlauf (Eds). Handbook of Economic Growth, Oxford, Oxford University Press.

North, Douglass C. 1990. Institutions, Institutional Change, and Economic Performance. Cambridge: Cambridge University Press.

Olson, Mancur. 1982. The Rise and Decline of Nations: Economic Growth, Stagflation, and Social Rigidities. New Haven: Yale University Press.

Praag, C. Mirjam van. 1999. Some Classic Views on Entrepreneurship. De Economist 147: 311-335.

Praag, C.M. van and H. van Ophem. 1995. Determinants of Willingness and Opportunity to Start as an Entrepreneur. Kyklos 48: 513-540.

Ricketts, Martin. 1987. The New Industrial Economics: An Introduction to Modern Theories of the Firm. New York: St. Martin's Press.

Romer, Paul. 1990. Endogenous Technological Change. Journal of Political Economy, vol. $98(5), 71-102$.

Russell, Alan and Jan Rath. 2002. Unravelling the Rag Trade: Immigrant Entrepreneurship in Seven World Cities. Oxford: Berg Publishers.

Sachs, Jeffrey D. and A. M. Warner. ÅRSTAL. Fundamental Sources of Long-Run Growth. American Economic Review 87: 184-188. 
Salerno, Joseph T. 1993. Mises and Hayek Dehomogenized. Review of Austrian Economics 6: $113-46$.

Schumpeter, Joseph A. 1911/1934 The Theory of Economic Development. Cambridge, MA: Harvard University Press,

Segerstrom, Paul S., T.C.A. Anant, and Elias Dinopoulos. 1990. A Schumpeterian Model of the Product Life Cycle. American Economic Review 80: 1077-1091.

Wennekers, Sander and Roy Thurik. 1999. Linking Entrepreneurship and Economic Growth. Small Business Economics 13: 27-55. 
Table 1. Descriptive statistics

\begin{tabular}{lccc}
\hline Variable & Mean & Standard deviation & Observations \\
\hline TEA & 8.0874 & 3.911 & 29 \\
TEAOPP & 5.519 & 2.807 & 29 \\
TEANEC & 2.095 & 1.836 & 29 \\
Log GDP & 9.731 & .584 & 29 \\
Postcommunist & .103 & .309 & 29 \\
Government size & 5.449 & 1.548 & 29 \\
$\quad$ Consumption, \% of & 23.031 & 8.849 & 29 \\
$\quad$ GDP & & & \\
$\quad$ Transfers, \% of GDP & 15.961 & 6.908 & 28 \\
$\quad$ Investment & 11.844 & 6.515 & 18 \\
$\quad$ Lack of taxation & 4.586 & 2.151 & 29 \\
Legal quality & 7.348 & 1.763 & 29 \\
Sound money & 8.879 & 1.394 & 29 \\
International trade & 7.821 & .774 & 29 \\
Regulatory quality & 6.241 & .847 & 29 \\
\hline
\end{tabular}


Table 2. Countries Included in This Study

\begin{tabular}{lccclccc}
\hline Country & TEA & TEAOPP & TEANEC & Country & TEA & TEAOPP & TEANEC \\
\hline Argentina & 9.6 & 5.3 & 4.1 & Mexico & 20.2 & 13.3 & 6.8 \\
Australia & 12.1 & 9.9 & 1.9 & Netherlands & 4.8 & 4.0 & 0.3 \\
Belgium & 3.4 & 2.6 & 0.6 & New Zealand & 15.2 & 12.4 & 2.5 \\
Brazil & 12.9 & 7.8 & 5.3 & Norway & 7.0 & 5.9 & 0.2 \\
Canada & 9.1 & 6.2 & 2.6 & Poland & 7.1 & 3.4 & 3.5 \\
Denmark & 5.6 & 4.6 & 0.3 & Portugal & 6.6 & 5.1 & 1.4 \\
Finland & 5.1 & 3.9 & 0.5 & Russia & 6.0 & 4.3 & 1.0 \\
France & 4.3 & 2.1 & 0.9 & Singapore & 5.9 & 4.6 & 1.1 \\
Germany & 5.8 & 4.1 & 1.4 & South Africa & 8.2 & 5.5 & 2.3 \\
Hungary & 10.9 & 7.6 & 3.2 & South Korea & 13.4 & 7.2 & 5.2 \\
India & 11.7 & 5.0 & 6.6 & Spain & 6.0 & 4.0 & 1.4 \\
Ireland & 9.7 & 7.2 & 1.8 & Sweden & 4.9 & 4.0 & 0.6 \\
Israel & 3.8 & 1.4 & 0.5 & United Kingdom & 5.2 & 3.5 & 0.9 \\
Italy & 8.2 & 6.3 & 1.7 & USA & 9.1 & 7.8 & 1.2 \\
Japan & 2.9 & 1.3 & 1.2 & & & & \\
\hline
\end{tabular}


Table 3. Macro Determinants of Entrepreneurial Activity

\begin{tabular}{|c|c|c|c|c|c|c|}
\hline & $\begin{array}{l}\text { TEA } \\
\text { OLS }\end{array}$ & $\begin{array}{l}\text { TEA } \\
\text { RR }\end{array}$ & $\begin{array}{c}\text { TEAOPP } \\
\text { OLS }\end{array}$ & $\begin{array}{c}\text { TEAOPP } \\
\text { RR }\end{array}$ & $\begin{array}{c}\text { TEANEC } \\
\text { OLS }\end{array}$ & $\begin{array}{c}\text { TEANEC } \\
\text { RR }\end{array}$ \\
\hline Log GDP & $\begin{array}{c}-3.909 * * * \\
(1.325)\end{array}$ & $\begin{array}{l}-3.989 * \\
(2.144)\end{array}$ & $\begin{array}{l}-1.725 \\
(1.038)\end{array}$ & $\begin{array}{l}-1.706 \\
(1.495)\end{array}$ & $\begin{array}{c}-2.413 * * * \\
(.338)\end{array}$ & $\begin{array}{c}-2.547 * * * \\
(.505)\end{array}$ \\
\hline Postcommunist & $\begin{array}{c}.863 \\
(1.318)\end{array}$ & $\begin{array}{c}.469 \\
(2.807)\end{array}$ & $\begin{array}{c}.886 \\
(1.136)\end{array}$ & $\begin{array}{c}.842 \\
(1.958)\end{array}$ & $\begin{array}{c}.378 \\
(.456)\end{array}$ & $\begin{array}{c}.308 \\
(.804)\end{array}$ \\
\hline Government size & $\begin{array}{c}2.124 * * * \\
(.692)\end{array}$ & $\begin{array}{c}2.321 * * * \\
(.721)\end{array}$ & $\begin{array}{c}1.740 * * * \\
(.404)\end{array}$ & $\begin{array}{c}1.712 * * * \\
(.503)\end{array}$ & $\begin{array}{l}.558 * * \\
(.243)\end{array}$ & $\begin{array}{c}.600 * * * \\
(.210)\end{array}$ \\
\hline Legal quality & $\begin{array}{c}.434 \\
(.644)\end{array}$ & $\begin{array}{c}.797 \\
(.883)\end{array}$ & $\begin{array}{l}.491 \\
(.494)\end{array}$ & $\begin{array}{c}.741 \\
(.616)\end{array}$ & $\begin{array}{c}.062 \\
(.197)\end{array}$ & $\begin{array}{c}.111 \\
(.259)\end{array}$ \\
\hline Sound money & $\begin{array}{c}2.077 * * * \\
(.714)\end{array}$ & $\begin{array}{c}2.582 \\
(1.728)\end{array}$ & $\begin{array}{c}1.304^{* * *} \\
(.493)\end{array}$ & $\begin{array}{c}1.729 \\
(1.205)\end{array}$ & $\begin{array}{c}.899 * * * \\
(.213)\end{array}$ & $\begin{array}{c}.937 * * * \\
(.247)\end{array}$ \\
\hline International trade & $\begin{array}{l}-1.255 \\
(.793)\end{array}$ & $\begin{array}{l}-1.840 \\
(1.144)\end{array}$ & $\begin{array}{l}-.787 \\
(.566)\end{array}$ & $\begin{array}{l}-1.131 \\
(.798)\end{array}$ & $\begin{array}{c}-.545^{* *} \\
(.250)\end{array}$ & $\begin{array}{l}-.529 * \\
(.312)\end{array}$ \\
\hline Regulatory quality & $\begin{array}{c}-.785 \\
(1.670)\end{array}$ & $\begin{array}{l}-1.442 \\
(1.757)\end{array}$ & $\begin{array}{c}-.449 \\
(1.047)\end{array}$ & $\begin{array}{c}-.872 \\
(1.225)\end{array}$ & $\begin{array}{l}-.420 \\
(.565)\end{array}$ & $\begin{array}{l}-.596 \\
(.508)\end{array}$ \\
\hline Observations & 29 & 29 & 29 & 29 & 29 & 29 \\
\hline Adjusted $\mathrm{R}^{2}$ & .526 & - & .409 & - & .832 & - \\
\hline F statistic & 4.11 & 2.52 & 2.94 & 2.22 & 14.86 & 11.24 \\
\hline RMSE & 2.740 & - & 2.196 & - & .766 & - \\
\hline
\end{tabular}

Note: all regressions include dummies for Asia, Sub-Saharan African, Latin America and the Caribbean, and the MENA region; ${ }^{* * *}(* *)[*]$ denotes significance at $\mathrm{p}<.01(\mathrm{p}<.05)[\mathrm{p}<.10]$. The variance inflation factor is 3.76 in all OLS regressions. Note also that actual trade does not matter. 
Table 4. Effects of Specific Factors of Government Size

\begin{tabular}{|c|c|c|c|c|c|c|c|c|}
\hline & TEANEC & TEANEC & TEANEC & TEANEC & TEAOPP & TEAOPP & TEAOPP & TEAOPP \\
\hline & 1 & 2 & 3 & 4 & 5 & 6 & 7 & 8 \\
\hline \multirow[t]{2}{*}{ Log GDP } & $-2.159 * * *$ & $-2.332 * * *$ & $-2.598 * * *$ & $-2.588 * * *$ & .008 & -.746 & $-4.021^{*}$ & -1.345 \\
\hline & $(.279)$ & $(.596)$ & $(.488)$ & $(.394)$ & $(.782)$ & $(1.324)$ & $(2.335)$ & (1.176) \\
\hline \multirow[t]{2}{*}{ Postcommunist } & -.417 & .566 & 2.334 & .476 & -1.895 & .619 & 9.514 & .591 \\
\hline & $(.775)$ & $(.654)$ & (1.602) & (.491) & (1.207) & (1.687) & $(6.458)$ & (1.705) \\
\hline \multirow[t]{2}{*}{ Sound money } & $.706^{* * *}$ & $.659^{* * *}$ & $1.113^{* * *}$ & $.652 * * *$ & $1.015^{* * *}$ & $1.132 * * *$ & $2.862 *$ & $1.007^{*}$ \\
\hline & $(.146)$ & $(.129)$ & $(.378)$ & (.122) & $(.306)$ & $(.513)$ & (1.534) & $(.537)$ \\
\hline \multicolumn{9}{|l|}{ Government: } \\
\hline Consumption, & $-.104 * * *$ & & & & $-.282 * * *$ & & & \\
\hline$\%$ of GDP & $(.021)$ & & & & $(.062)$ & & & \\
\hline Transfers, $\%$ & & -.060 & & & & $-.277 * *$ & & \\
\hline of GDP & & $(.038)$ & & & & $(.131)$ & & \\
\hline \multirow[t]{2}{*}{ Investment } & & & -.106 & & & & -.019 & \\
\hline & & & $(.069)$ & & & & $(.227)$ & \\
\hline Lack of & & & & .139 & & & & $.549 * *$ \\
\hline taxation & & & & $(.093)$ & & & & $(.272)$ \\
\hline Observations & 29 & 28 & 18 & 29 & 29 & 28 & 29 & 29 \\
\hline Adjusted R & .874 & .792 & .786 & .785 & .353 & .211 & .109 & .286 \\
\hline \multicolumn{9}{|l|}{ Square } \\
\hline F statistic & 28.84 & 15.70 & 9.89 & 13.53 & 3.18 & 2.03 & - & \\
\hline RMSE & .662 & .863 & 1.001 & .919 & 2.298 & 2.475 & 3.315 & 2.788 \\
\hline
\end{tabular}

Note: all regressions include dummies for Asia, Sub-Saharan African, Latin America and the Caribbean, and the MENA region. 
Figure 1. Government and Entreprenurial Activity

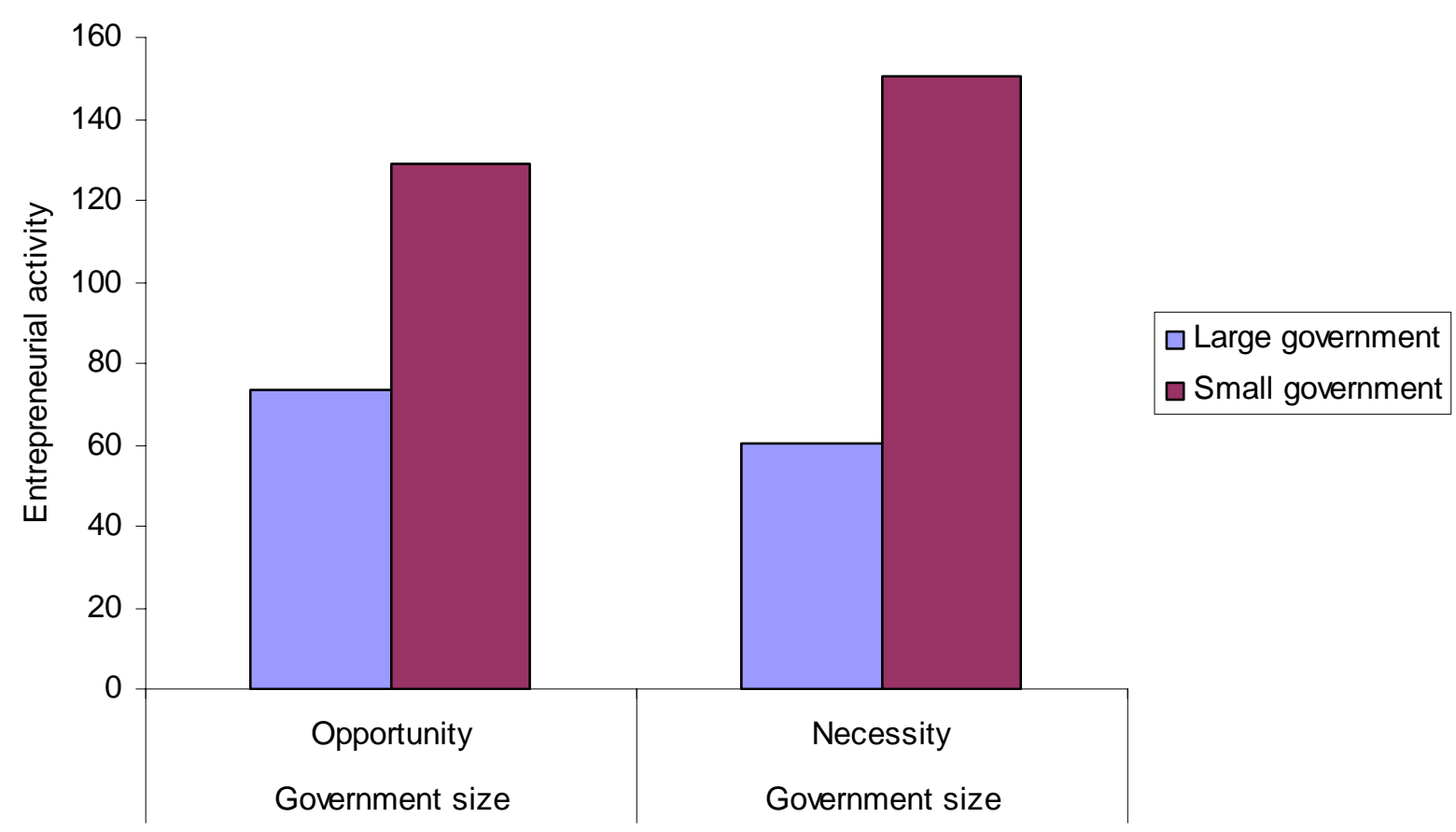




\section{SMG - Working Papers \\ www.cbs.dk/smg \\ 2003}

2003-1: Nicolai J. Foss, Kenneth Husted, Snejina Michailova, and Torben Pedersen: Governing Knowledge Processes: Theoretical Foundations and Research Opportunities.

2003-2: Yves Doz, Nicolai J. Foss, Stefanie Lenway, Marjorie Lyles, Silvia Massini, Thomas P. Murtha and Torben Pedersen: Future Frontiers in International Management Research: Innovation, Knowledge Creation, and Change in Multinational Companies.

2003-3: Snejina Michailova and Kate Hutchings: The Impact of In-Groups and OutGroups on Knowledge Sharing in Russia and China CKG Working Paper.

2003-4: Nicolai J. Foss and Torben Pedersen : The MNC as a Knowledge Structure: The Roles of Knowledge Sources and Organizational Instruments in MNC Knowledge Management CKG Working Paper.

2003-5: Kirsten Foss, Nicolai J. Foss and Xosé H. Vázquez-Vicente: “Tying the Manager's Hands": How Firms Can Make Credible Commitments That Make Opportunistic Managerial Intervention Less Likely CKG Working Paper.

2003-6: Marjorie Lyles, Torben Pedersen and Bent Petersen: Knowledge Gaps: The Case of Knowledge about Foreign Entry.

2003-7: Kirsten Foss and Nicolai J. Foss: The Limits to Designed Orders: Authority under "Distributed Knowledge" CKG Working Paper.

2003-8: Jens Gammelgaard and Torben Pedersen: Internal versus External Knowledge Sourcing of Subsidiaries - An Organizational Trade-Off.

2003-9: Kate Hutchings and Snejina Michailova: Facilitating Knowledge Sharing in Russian and Chinese Subsidiaries: The Importance of Groups and Personal Networks Accepted for publication in Journal of Knowledge Management.

2003-10: Volker Mahnke, Torben Pedersen and Markus Verzin: The impact of knowledge management on MNC subsidiary performance: the role of absorptive capacity CKG Working Paper.

2003-11: Tomas Hellström and Kenneth Husted: Mapping Knowledge and Intellectual Capital in Academic Environments: A Focus Group Study Accepted for publication in Journal of Intellectual Capital CKG Working Paper.

2003-12: Nicolai J Foss: Cognition and Motivation in the Theory of the Firm: Interaction or "Never the Twain Shall Meet"? Accepted for publication in Journal des Economistes et des Etudes Humaines CKG Working Paper.

2003-13: Dana Minbaeva and Snejina Michailova: Knowledge transfer and expatriation practices in MNCs: The role of disseminative capacity.

2003-14: Christian Vintergaard and Kenneth Husted: Enhancing selective capacity through venture bases. 


\section{4}

2004-1: Nicolai J. Foss: Knowledge and Organization in the Theory of the Multinational Corporation: Some Foundational Issues

2004-2: Dana B. Minbaeva: HRM practices and MNC knowledge transfer

2004-3: Bo Bernhard Nielsen and Snejina Michailova: Toward a phase-model of global knowledge management systems in multinational corporations

2004-4: Kirsten Foss \& Nicolai J Foss: The Next Step in the Evolution of the RBV: Integration with Transaction Cost Economics

2004-5: Teppo Felin \& Nicolai J. Foss: Methodological Individualism and the Organizational Capabilities Approach

2004-6: Jens Gammelgaard, Kenneth Husted, Snejina Michailova: Knowledge-sharing Behavior and Post-acquisition Integration Failure

2004-7: Jens Gammelgaard: Multinational Exploration of Acquired R\&D Activities

2004-8: Christoph Dörrenbächer \& Jens Gammelgaard: Subsidiary Upgrading? Strategic Inertia in the Development of German-owned Subsidiaries in Hungary

2004-9: Kirsten Foss \& Nicolai J. Foss: Resources and Transaction Costs: How the Economics of Property Rights Furthers the Resource-based View

2004-10: Jens Gammelgaard \& Thomas Ritter: The Knowledge Retrieval Matrix: Codification and Personification as Separate Strategies

2004-11: Nicolai J. Foss \& Peter G. Klein: Entrepreneurship and the Economic Theory of the Firm: Any Gains from Trade?

2004-12: Akshey Gupta \& Snejina Michailova: Knowledge Sharing in Knowledge-Intensive Firms: Opportunities and Limitations of Knowledge Codification

2004-13: Snejina Michailova \& Kate Hutchings: Knowledge Sharing and National Culture: A Comparison Between China and Russia

\section{5}

2005-1: Keld Laursen \& Ammon Salter: My Precious - The Role of Appropriability Strategies in Shaping Innovative Performance

2005-2: Nicolai J. Foss \& Peter G. Klein: The Theory of the Firm and Its Critics: A Stocktaking and Assessment

2005-3: Lars Bo Jeppesen \& Lars Frederiksen: Why Firm-Established User Communities Work for Innovation: The Personal Attributes of Innovative Users in the Case of Computer-Controlled Music

2005-4: Dana B. Minbaeva: Negative Impact of Hrm Complementarity on Knowledge Transfer in Mncs

2005-5: Kirsten Foss, Nicolai J. Foss, Peter G. Klein \& Sandra K. Klein: Austrian Capital Theory and the Link Between Entrepreneurship and the Theory of the Firm 
2005-1: Nicolai J. Foss: The Knowledge Governance Approach

2005-2: Torben J. Andersen: Capital Structure, Environmental Dynamism, Innovation Strategy, and Strategic Risk Management

2005-3: Torben J. Andersen: A Strategic Risk Management Framework for Multinational Enterprise

2005-4: Peter Holdt Christensen: Facilitating Knowledge Sharing: A Conceptual Framework

2005-5 Kirsten Foss \& Nicolai J. Foss: Hands Off! How Organizational Design Can Make Delegation Credible

2005-6 Marjorie A. Lyles, Torben Pedersen \& Bent Petersen: Closing the Knowledge Gap in Foreign Markets - A Learning Perspective

2005-7 Christian Geisler Asmussen, Torben Pedersen \& Bent Petersen: How do we capture "Global Specialization" when measuring firms' degree of internationalization?

2005-8 Kirsten Foss \& Nicolai J. Foss: Simon on Problem-Solving: Implications for New Organizational Forms

2005-9 Birgitte Grøgaard, Carmine Gioia \& Gabriel R.G. Benito: An Empirical Investigation of the Role of Industry Factors in the Internationalization Patterns of Firms

2005-10 Torben J. Andersen: The Performance and Risk Management Implications of Multinationality: An Industry Perspective

2005-11 Nicolai J. Foss: The Scientific Progress in Strategic Management: The case of the Resource-based view

2005-12 Koen H. Heimeriks: Alliance capability as a mediator between experience and alliance performance: An empirical investigation into the alliance capability development process

2005-13 Koen H. Heimeriks, Geert Duysters \& Wim Vanhaverbeke: Developing Alliance Capabilities: An Empirical Study

2005-14 JC Spender: Management, Rational or Creative? A Knowledge-Based Discussion

\section{6}

2006-1: Nicolai J. Foss \& Peter G. Klein: The Emergence of the Modern Theory of the Firm

2006-2: Teppo Felin \& Nicolai J. Foss: Individuals and Organizations: Thoughts on a Micro-Foundations Project for Strategic Management and Organizational Analysis

2006-3: Volker Mahnke, Torben Pedersen \& Markus Venzin: Does Knowledge Sharing Pay? An MNC Subsidiary Perspective on Knowledge Outflows

2006-4: Torben Pedersen: Determining Factors of Subsidiary Development 
2006-5 Ibuki Ishikawa: The source of competitive advantage and entrepreneurial judgment in the RBV: Insights from the Austrian school perspective

2006-6 Nicolai J. Foss \& Ibuki Ishikawa: Towards a dynamic resource-based view: Insights from Austrian capital and entrepreneurship theory

2006-7 Kirsten Foss \& Nicolai J. Foss: Entrepreneurship, Transaction Costs, and Resource Attributes

2006-8 Kirsten Foss, Nicolai J. Foss \& Peter G. Klein: Original and Derived Judgement: An Entrepreneurial Theory of Economic Organization

2006-9 Mia Reinholt: No More Polarization, Please! Towards a More Nuanced Perspective on Motivation in Organizations

2006-10 Angelika Lindstrand, Sara Melen \& Emilia Rovira: Turning social capital into business? A study of Swedish biotech firms' international expansion

2006-11 Christian Geisler Asmussen, Torben Pedersen \& Charles Dhanaraj: Evolution of Subsidiary Competences: Extending the Diamond Network Model

2006-12 John Holt, William R. Purcell, Sidney J. Gray \& Torben Pedersen: Decision Factors Influencing MNEs Regional Headquarters Location Selection Strategies

2006-13 Peter Maskell, Torben Pedersen, Bent Petersen \& Jens Dick-Nielsen: Learning Paths to Offshore Outsourcing - From Cost Reduction to Knowledge Seeking

2006-14 Christian Geisler Asmussen: Local, Regional or Global? Quantifying MNC Geographic Scope

2006-15 Christian Bjørnskov \& Nicolai J. Foss: Economic Freedom and Entrepreneurial Activity: SOME CROSS-COUNTRY EVIDENCE 